УДК 619:636.7. 619:616-091

doi: $10.36359 /$ scivp.2019-20-2.30

\title{
ГІСТОЛОГІЧНІ ТА ГІСТОХІМІЧНІ ЗМІНИ В НИРКАХ СОБАК ЗА ОТРУСННЯ ІЗОНІАЗИДОМ
}

\author{
Г. І. Кочюмбас, д-р вет. наук, професор, \\ Н. П. Вреиьона, аспірант
}
Львівський національний університет ветеринарної медицини та біотехнологій імені С.3. Гжицького, вул. Пекарська, 50, м. Львів, 79010, Україна

У статті представлені результати макроскопічних, гістологічних та гістохімічних досліджень нирок собак за отруєння ізоніазидом. Проведено патологоанатомічний розтин 19 трупів собак різного віку та породи, відібрано фрагменти нирок для морфологічних досліджень. Взіриі нирок фіксували в 10 \% водному розчині нейтрального формаліну, рідині Карнуа і Буена. Зневоднення проводили в етанолі зростаючої концентрачії та заливали в парафін. Зрізи виготовляли на мікротомі МC-2 товщиною 7 мкм, фарбували гематоксиліном та еозином, за методикою Мак-Мануса і Перлса. Виготовлені гістопрепарати розглядали під світловим мікроскопом Leica DM 2500 (Switzerland), фотофіксаиію здійснювали фотокамерою Leica DFC450C з використанням програмного забезпечення Leica Application Suite Version 4.4. Макроскопічно нирки кровонаповнені, бобоподібної форми, збільшені в об'ємі. Поверхня органу гладка, волокниста капсула нирки знімалась легко, на розрізі межа між кірковою і мозковою речовиною виражена. Кіркова речовина забарвлена у коричневовишневий колір, в той час як мозкова речовина - червоно-рожевого відтінку. 3 поверхні розрізу кіркової речовини стікала венозна кров. За гістологічного дослідження у нирках встановлено: гіперемія, стаз, діапедезні крововиливи, гемоліз еритрочитів, який супроводжував відкладання гранул гемосидерину та білірубіну в епітелії канальців та макрофагів; плазматичне просякання і накопичення глікопротеїнів у стінках капілярів клубочка, капсули Шумлянського-Боумена, артеріолах та у стромальних елементах інтерстицію; $у$ проксимальних звивистих канальиях нирок превалювали гідропічна дистрофія та некробіоз, що вказувало на розвиток некротичного тубулонефрозу. Виявлені мікроструктурні зміни нирок загиблих собак відзначались не однотипністю в структурах кіркової та мозкової речовини, але спільним було прогресуюче порушення гемодинаміки та руйнування клітинних елементів.

Ключові слова: СОБАКА, НИРКИ, МІКРОСТРУКТУРНІ ЗМІНИ, ОТРУЄННЯ, ІЗОНІАЗИД, ГІСТОЛОГІЯ, ГІСТОХІМІЯ.

Ізоніазид (гідразид ізонікотинової кислоти) - протитуберкульозний медичний препарат, який широко застосовують фтизіатри при лікуванні людей, а застосування даного препарату собакам спричиняє в них гостре отруєння. Оскільки летальна доза $\mathrm{LD}_{50}$ ізоніазиду для собак описана за експериментального дослідження і становить 50 мг/кг [1]. Першими розробниками даної хімічної сполуки були вчені з Праги Meyer H. та Mally J., які в 1912 р. 3 етилізонікотинату i гідразину синтезували ізоніазид, похідний піридину. У 1926 p. Качугін А. Т. створив на його основі лікарський препарат під назвою «тубазид» [2].

Відомо, що ізоніазид добре проникає через тканинні бар'єри і після смерті тварин, що загинули внаслідок отруєння, максимальна кількість препарату виявляється в сечі, дещо менше в нирках і значно менше - в шлунково-кишковому тракті, печінці, легенях. Через 3-6 годин після прийому концентрація препарату різко знижується у всіх органах, крім нирок [3]. 
При цьому, слід зазначити, що не зв'язаний ізоніазид проходить через клубочковий фільтр, а кон'югований з білками сироватки крові виділяється в канальці нирок [4].

Нирки, як головний екскреторний орган, є мішенню для багатьох ксенобіотиків. Високий рівень кровопостачання та велика протяжність тубулярного апарату обумовлюють тривалість контакту токсичних речовин та їх метаболітів з ендотелієм кровоносних судин, нирковим епітелієм та клітинами інтерстицію. Зрозуміло, що нефротоксична дія розвивається при досягненні критичної концентрації токсиканта у клітинах [5]. Токсикант, який пройшов через фільтраційний бар'єр у клубочках, концентрується всередині канальців, а у силу реабсорбції більшої частини води, що міститься в первинній сечі, ксенобіотики надходять у клітини канальцевого епітелію, там накопичуються. Більшість хімічних речовин здатні викликати різні форми ниркових уражень, тому в обов'язковому порядку необхідно вивчати їх гістоструктурні ураження. Тому метою нашої роботи було вивчити морфофункціональні зміни в нирках за гострого отруєння собак ізоніазидом.

Матеріали і методи. Проведено патологоанатомічний розтин i токсикологічні дослідження патологічного матеріалу від 19 трупів собак різного віку та породи. Під час патологоанатомічного розтину було відібрано фрагменти нирок для морфологічного дослідження. Взірці нирок фіксували в 10 \% водному розчині нейтрального формаліну, рідині Карнуа і Буена. Зневоднення проводили в етанолі зростаючої концентрації та заливали в парафін [6]. Зрізи виготовляли на мікротомі МC-2 товщиною 7 мкм, фарбували гематоксиліном та еозином, за метододикою Мак-Мануса і Перлса [7]. Виготовлені гістопрепарати розглядали під світловим мікроскопом Leica DM 2500 (Switzerland), фотофіксацію здійснювали фотокамерою Leica DFC450C 3 використанням програмного забезпечення Leica Application Suite Version 4.4.

Результати й обговорення. Під час розтину трупів тварин, які загинули від отруєння ізоніазидом, макроскопічно відзначали помірно виражені зміни в нирках. Нирки кровонаповнені, бобоподібної форми, збільшені в об'ємі. Поверхня органу гладка, волокниста капсула нирки знімалась легко, на розрізі межа між кірковою та мозковою речовиною виражена (рис. 1). Кіркова речовина забарвлена у коричнево-вишневий колір, в той час як мозкова речовина - червоно-рожевого відтінку. 3 поверхні розрізу кіркової речовини стікала венозна кров. Сечовий міхур, у більшості загиблих собак, розширений та переповнений прозорою, охряно-жовтого кольору сечею. Під серозною оболонкою сечового міхура відзначали значне розширення та переповнення кров'ю судин (рис. 2). Слизова оболонка сечового міхура блідо-рожевого кольору.



Рuс. 1. Нирки бобоподібної форми, кіркова речовина інтенсивно кровонаповнена

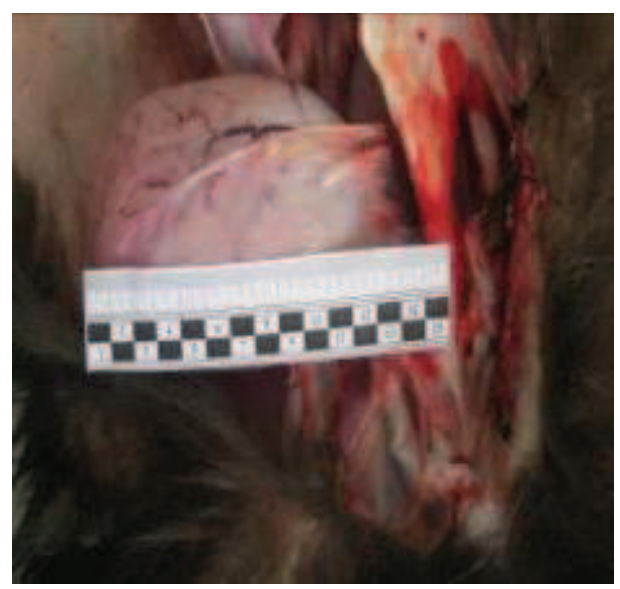

Рuс. 2. Сечовий міхур переповнений сечею, судини розширені

За гістологічного дослідження нирок загиблих собак відзначали не однотипні зміни в структурах кіркової та мозкової речовини, але спільним було прогресуюче порушення 
гемодинаміки та руйнування клітинних елементів. Оскільки з током крові в нирки потрапляли продукти розпаду ізоніазиду, то це, в першу чергу, зумовило порушення структури макро- i мікроциркуляторного русла, що вело до розвитку гіпоксії.

У нирках одних особин, на тлі вираженої гіперемії (переповнення капілярної сітки клубочка та судин еритроцитами) превалювало набухання, некробіоз і відшарування ендотеліальних клітин, що вело до плазморагії і мукоїдного набухання петель капілярів клубочків (рис. 3). Мукоїдний набряк простежувався і у стромі органу. В розширених просвітах інтерстиції, а також в структурі базальних мембран звитих канальців, відзначали нагромадження глікопротеїнів. На препаратах, забарвлених за Мак-Манусом, мембрани базальних мембран капілярів клубочків, зовнішнього листка гломерулярної капсули та просвіту інтерстицію набували інтенсивно малинового забарвлення (рис 4).

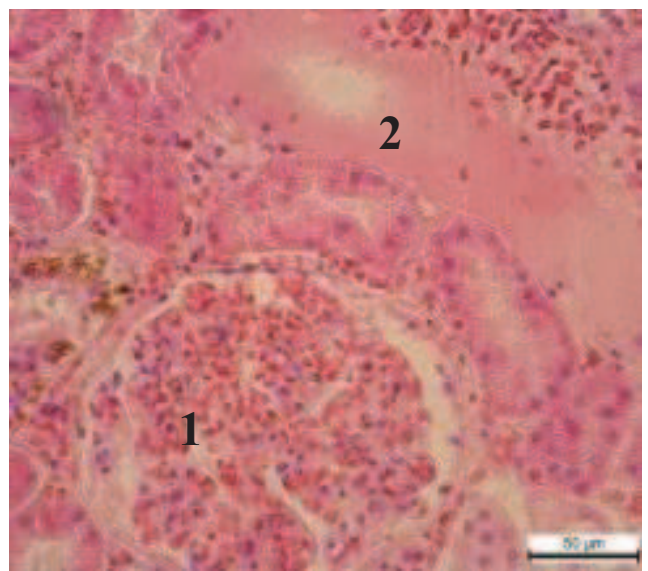

Puс. 3. Нирка. Переповнення капілярів клубочків еритроцитами (1). Порушення структури ендотелію, накопичення плазми крові у просвіті судин (2). Гематоксилін-еозин. Ок.10, об. 40

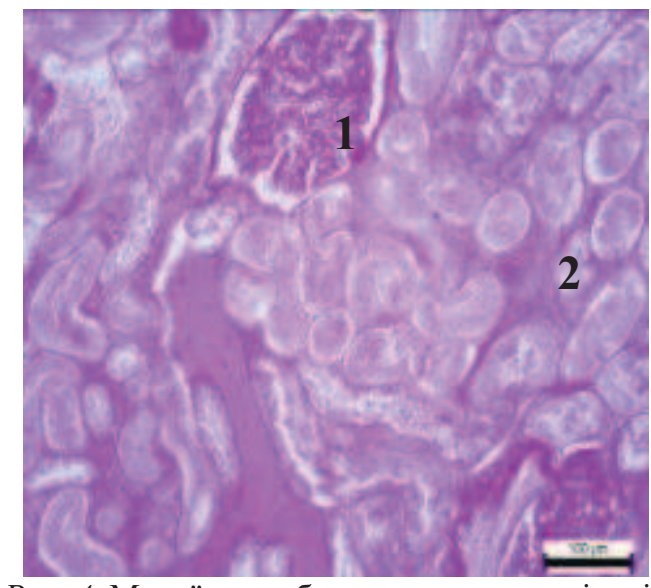

Puc. 4. Мукоїдне набухання петель капілярів клубочків (1), інтерстицію та просякання їх PAS позитивними речовинами (2). Мак-Манус. Ок. 10, об. 40

Відомо, що у нормі через клубочковий фільтраційний бар'єр не проходять формені елементи крові та білки плазми крові з великою молекулярною масою, а виявлення PAS позитивних речовин в структурі базальних мембран вказало на просякання цих структур глікопротеїнами. Це вело до порушення прохідності капілярів і розвитку гломерулярних гемодинамічних порушень.

Капсула Шумлянського-Боумена розширена, потовщена за рахунок просякання білками крові. Відзначали також дезорганізацію основної речовина і колагенових волокон. Виявлені зміни вказували на значне виділення білка крові внаслідок підвищеної проникності ендотелію до альбумінів, глобулінів та фібриногену, що супроводжувалось різким зменшення його вмісту в самій крові та дезорганізаційними процесами в сполучнотканинних структурах.

Крім того, простежували внутрішньосудинну коагуляцію у дрібних артеріолах кіркового шару - утворення еритроцитарних агрегатів та заповнення венул плазмою крові (рис. 5). У мозковому шарі візуалізувались дрібні осередки діапедезних крововиливів (рис. 6). На різко виражене порушення складу та реологічних властивостей крові вказував гемоліз еритроцитів, нагромадження плазми крові в просвіті судин.

Зростання продуктів розпаду еритроцитів відобразилось нагромадженням гемосидерину в макрофагах та епітелії проксимальних канальців. На препаратах, забарвлених за Перлсом, світло-сині гранули гемосидерину добре візуалізувались у цитоплазмі макрофагів та цитоплазмі епітеліальних клітин проксимальних канальців (рис. 7, рис. 8). 




Рис. 5. Нирка. Утворення еритроцитарних агрегатів у мікросудинах (1), заповнення венул плазмою крові (2). Гематоксилін-еозин. Ок.10, об. 40

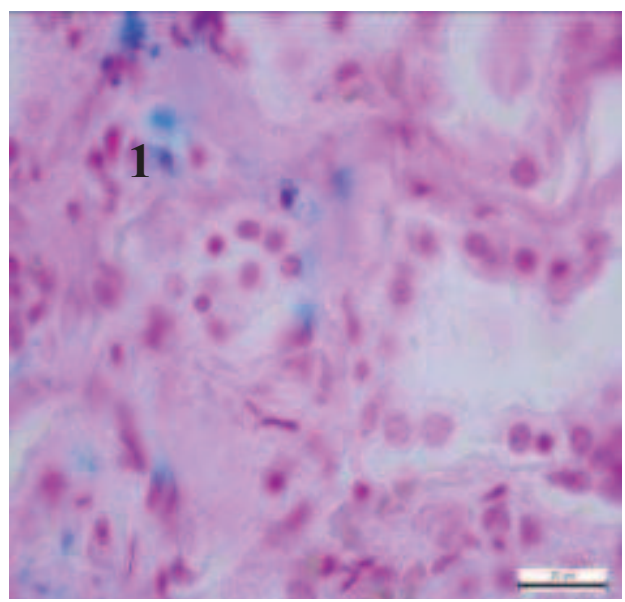

Puc. 7. Нирка. Нагромадження гемосидерину в цитоплазмі макрофагів (1). Перлс. Ок.10, об. 100

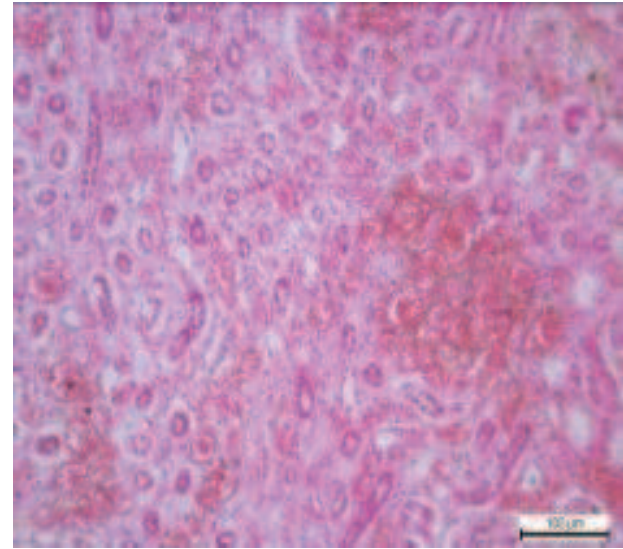

Рис. 6. Нирка. Порушення структури судин, вихід крові за межі судин і накопичення крові у просвіті прямих канальців. Гематоксилін-еозин. Ок.10, об. 20

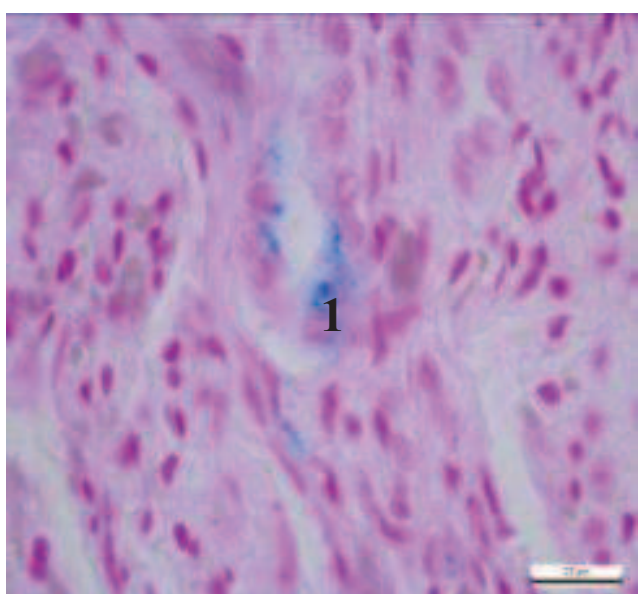

Рuc. 8. Нирка. Гемосидерин в епітелії проксимальних звивистих канальців (1). Перлс. Ок.10, об. 100

На посилений гемоліз еритроцитів за отруєння собак ізоніазидом вказувало також відкладання гранул білірубіну як у стінках судин, макрофагах інтерстицію, так і в епітелії звивистих канальців. Гранули золотисто-жовтого пігменту білірубіну добре візуалізувались в цитоплазмі макрофагів і епітелії канальців (рис. 9, рис. 10).

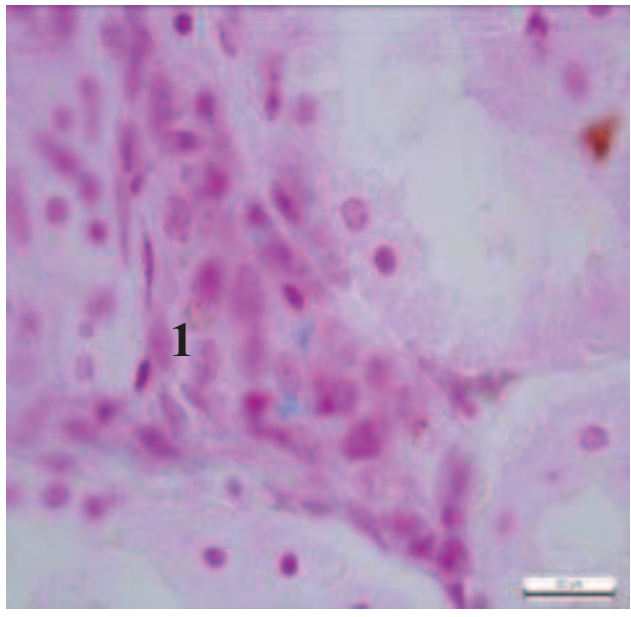

Puc. 9. Нирка. Нагромадження гранул білірубіну в цитоплазмі макрофагів (1). Перлс. Ок.10, об. 100.



Puc. 10. Нирка. Гранули білірубіну в цитоплазмі епітеліальних клітин канальців (1). Гематоксилін та еозин. Ок.10, об. 40. 
Зміни в судинній системі поєднувались з важкими процесами в тубулярній системі. Зрозуміло, що внаслідок гемолізу еритроцитів різко падала киснева (оксигенна) наповненість крові і розвивалась аноксемія, а проникнення з током крові токсичних продуктів в структури, де проходить активна фільтрація та реабсорбція, спричинило руйнування клітинних елементів нефронів.

Пошкодження клубочків супроводжувалося важкими змінами у канальцях. Контури проксимальних канальців згладжені. В деяких канальцях епітеліальні клітини набубнявілі, ядра зміщені на периферію, ближче до базальної мембрани (рис. 11). У переважної більшості канальців відзначали лізис ядер, гомогенізацію цитоплазми. Клітинні пласти канальців набували еозинофільного забарвлення і злущувались у їх просвіт, що вказувало на розвиток гострого некрозу канальців (рис. 12).



Рис. 11. Нирка. Епітеліальні клітини канальців набубнявілі, ядра зміщені на периферію, ближче до базальної мембрани (1). Гематоксилін та еозин. Ок. 10, об. 40

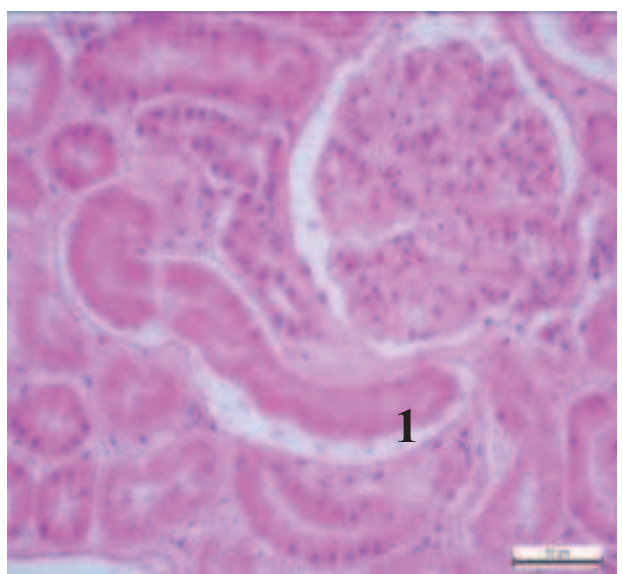

Рuc. 12. Нирка. Лізис ядер, гомогенізація цитоплазми епітелію звивистих канальців нирок (1).

Гематоксилін та еозин. Ок.10, об. 40

Виражені дистрофічно-некробіотичні зміни в епітелії проксимальних і дистальних нефронів зумовили сильне звуження просвіту самих канальців. Внаслідок таких змін, утворений клубочковий фільтрат через пошкоджені стінки канальців не тільки проникав по капілярам і лімфатичним судинам у кров, але й в значній мірі потрапляв у інтерстицій, що сприяло розвитку набряку.

В інших випадках у капілярній сітці клубочків та венозних судинах нирок собак, що загинули від гострого отруєння ізоніазидом, превалювало накопичення плазми 3 малочисленною кількістю формених елементів крові. У прегломерулярнитх артеріолах просвіт різко звужений, без формених елементів крові. Просвіт проксимальних канальців, внаслідок набухання епітелію та некронефротичних змін в них також звужений. У стінках капілярів, судин ядра ендотелію в стані рексису, пікнозу і лізису. Помітне сильно виражене плазматичне просякання строми органу (рис. 13, 14). Підвищена проникність клубочкового фільтра призвела до надходження в сечовий просвіт білка та інших субстанцій, що, зрозуміло, супроводжувалось деструкцією гломерул, втратою нефронів та вказувало на гостру ниркова недостатність.

Отже, за отруєння собак ізоніазидом зміни в нирках характеризувались різким порушенням реологічних властивостей та складу крові, що, в свою чергу, призвели до розвитку аноксеемії і супроводжувались плазматичним просяканням, мукоїдним набуханням стінок судин і стромальних елементів. Відкладання гранул гемосидерину та білірубіну в цитоплазму макрофагів та епітелію проксимальних канальців вказувало на внутрішньосудинний гемоліз еритроцитів. 




Рuc. 13. Плазма у просвіті клубочків нирок. Гематоксилін-еозин. Ок.10, об. 40

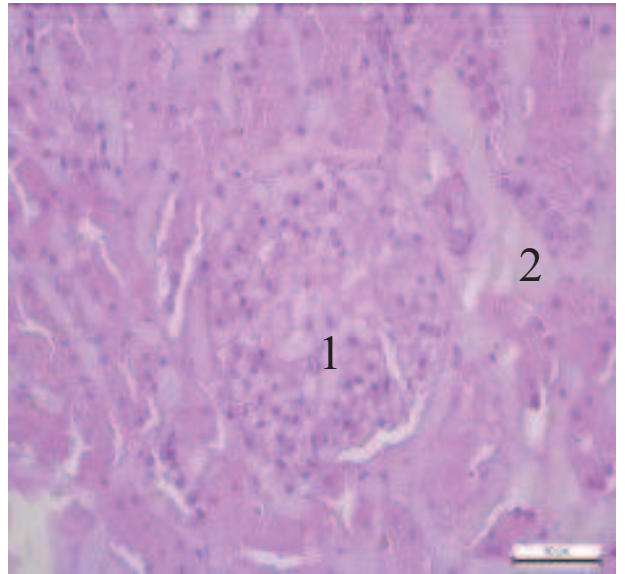

Puc. 14. Нирки. Плазма крові у просвіті клубочка (1) та в інтерстиції стінок судин (2). Гематоксилін-еозин. Ок. 10 , об. 20

На тлі виражених змін в судинно-стромальній системі та крові прогресували дистрофічно-некробіотичні зміни в системі клубочкової фільтрації та канальцевої реабсорбції.

На нашу думку, в аспекті патогенезу отруєння собак ізоніазидом необхідно виділити: різке порушення реологічних властивостей і складу крові, аноксеемію, накопичення продуктів пероксидації та інших токсичних продуктів, що спричинило гемоліз еритроцитів, і на мікроструктурному рівні виразилось гіперемією, стазом, діапедезними крововиливами, відкладанням гранул гемосидерину та білірубіну в епітелію канальців і макрофагів, плазматичним просяканням стінок судин, структур строми, дистрофічно-некробіотичними процесами в епітелії канальців нирок і вказувало на розвиток некротичного тубулонефрозу.

Відкладання гранул гемосидерину та білірубіну виявлено нами також в гістіоцитах та купферівських клітинах печінки собак за отруєння ізоніазидом [8], що дозволяє стверджувати про внутрішньосудинний гемоліз еритроцитів та розвиток загального гемосидерозу.

Відомо, що за впливу ізоніазиду в організмі собак відбувається порушення метаболізму піридоксину та зниження його рівня в плазмі крові і в тканинах. Сповільнюється утворення НАД, порушується аеробне окислення глюкози, $\beta$-окислення жирних кислот, розвивається тканинна гіпоксія. При цьому тварин поділяють на «швидких» та «повільних» ацетиляторів, що пов'язано з роботою $\mathrm{N}$-ацетилтрансферази, активність якої у собак є низькою і тому знешкодження продуктів розпаду ізоніазиду проходить повільно, що сприяє швидкому проникненню їх у кров [9]. Тканинна гіпоксія призводить до порушення обміну речовин, накопичення продуктів неповного окиснення, що зумовлює важкі незворотні патологічні зміни в органах і тканинах.

\section{В И С Н О В К И}

1. У нирках, за отруєння собак ізоніазидом, встановлено:

- гіперемію, стаз, діапедезні крововиливи, гемоліз еритроцитів, який супроводжував відкладання гранул гемосидерину та білірубіну в макрофагах та епітелію канальців нирок;

- плазматичне просякання і накопичення глікопротеїнів у стінках капілярів клубочка, капсули Шумлянського-Боумена, артеріолах та у стромальних елементах інтерстицію;

- у проксимальних звивистих канальцях нирок превалювали гідропічна дистрофія та некробіоз, що вказувало на розвиток некротичного тубулонефрозу.

2. Вивлений на морфологічному рівні гемоліз еритроцитів, підвищена плазморагія та руйнування стромальних елементів вказували на розвиток гіпоксичного стану і аноксемії.

Перспективи досліджень. Вивчення ультраструктурних змін в центральній нервової системи собак за отруєння ізоніазидом. 


\title{
HISTOLOGICAL AND HISTOCHEMICAL CHANGES IN DOGS' KIDNEYS FOR ISONIAZID POISONING
}

\author{
H. I. Kotsyumbas, N. P. Vretsona
}

Lviv National University of Veterinary Medicine and Biotechnologies named after S. Z. Gzhytskyi 50, Pekarska str., Lviv, 79010, Ukraine

\section{S U M M A R Y}

The article presents the results of macroscopic, histological and histochemical studies of dogs' kidneys for isoniazid poisoning.

The path-anatomical section of 19 corpses of dogs of all ages and breeds has been carried out. Kidney fragments for morphological research have been selected. The kidney samples were fixed in a 10\% aqueous solution of neutral formalin, Carnoua and Buena liquids. Dehydration was carried out in ethanol of increasing concentration and poured into paraffin. The slices were made on a microtome MC-2 in a thickness of 7 microns, stained with hematoxylin and eosin, according to the McManus and Pearl methodology. The produced histoplasts were examined under a light microscope Leica DM 2500 (Switzerland), photo-confirmed with the Leica DFC450C camera using the Leica Application Suite Version 4.4 software.

Macroscopic kidney blood filling, beanlike form, increased in volume. The surface of the organ is smooth, the fibrous kidney capsule was removed easily, in the cut border between the cortical and cerebrospinal fluid is expressed. The brilliant substance is colored in brownish-cherry color, while the cerebellum is a reddish-pinkish tint. Venous blood flowed from the cut surface of the cortical substance.

For histological examination in the kidneys it was determined: hyperemia, stasis, diapedeous hemorrhage, hemolysis of erythrocytes, which was accompanied by the deposition of hemosiderin granules and bilirubin in the epithelium of the tubules and macrophages; plasma penetration and accumulation of glycoproteins in the walls of the glomerular capillaries, Shumlyansky-Bowman capsules, arterioles, and in stromal elements of interstitium; in proximal convoluted tubules of the kidneys, hydropsical dystrophy and necrobiosis prevailed, indicating the development of necrotic tubulonephrosis. The revealed microstructural changes of the kidneys of dead dogs were not of the same type in the structures of the cortical and cerebral matter, but there was a general progressive violation of hemodynamics and destruction of cellular elements.

Keywords: DOG, KIDNEYS, MICROSTRUCTURAL CHANGES, POISONING, ISONIAZID, HISTOLOGY, HISTOCHEMISTRY.

\section{ГИСТОЛОГИЧЕСКИЕ И ГИСТОХИМИЧЕСКИЕ ИЗМЕНЕНИЯ В ПОЧКАХ СОБАК ПРИ ОТРАВЛЕНИИ ИЗОНИАЗИДОМ}

\author{
Г. И. Коиюмбас, Н. П. Врецеёна
}

Львовский национальный университет ветеринарной медицины и биотехнологий имени С.3. Гжицкого, ул. Пекарская, 50, г. Львов, 79010, Украина

\section{А Н Н О Т А ЦИ Я}

В статье представлены результаты макроскопических, гистологических и гистохимических исследований почек собак при отравлении изониазидом.

Проведено патологоанатомическое вскрытие 19 трупов собак разного возраста и породы, отобраны фрагменты почек для морфологических исследований. Образцы почек 
фиксировали в 10\% водном растворе нейтрального формалина, жидкости Карнуа и Буэна. Обезвоживание проводили в этаноле возрастающей концентрации и заливали в парафин. Срезы изготавливали на микротоме МС-2 толщиной 7 мкм, окрашивали гематоксилином и эозином, по методике Мак-Мануса и Перлса. Изготовленные гистопрепараты рассматривали под световым микроскопом Leica DM 2500 (Switzerland), фотофиксацию осуществляли фотокамерой Leica DFC450C с использованием программного обеспечения Leica Application Suite Version 4.4.

Макроскопически почки кровенаполненные, бобовидной формы, увеличены в объеме. Поверхность органа гладкая, волокнистая капсула почки снималась легко, на разрезе граница между корковым и мозговым веществом выражена. Корковое вещество окрашена в коричнево-вишневый цвет, в то время как мозговое вещество - красно-розового оттенка. С поверхности разреза коры стекала венозная кровь.

При гистологическом исследовании в почках установлены: гиперемия, стаз, диапедезные кровоизлияния, гемолиз эритроцитов, который сопровождал отложения гранул гемосидерина и билирубина в эпителии канальцев и макрофагов; плазматическое пропитывания и накопления гликопротеинов в стенках капилляров клубочка, капсулы Шумлянского-Боумена, артериолах и в стромальных элементах интерстиция; в проксимальных извитых канальцах почек превалировали гидропическая дистрофия и некробиоз, что указывало на развитие некротического тубулонефроза. Обнаруженные микроструктурные изменения почек погибших собак отмечались не однотипностью в структурах коркового и мозгового вещества, но общим было прогрессирующее нарушение гемодинамики и разрушения клеточных элементов.

Ключевые слова: СОБАКА, ПОЧКИ, МИКРОСТРУКТУРНЫЕ ИЗМЕНЕНИЯ, ОТРАВЛЕНИЕ, ИЗОНИАЗИД, ГИСТОЛОГИЯ, ГИСТОХИМИЯ.

\section{Л I T E P A T У P A}

1. Toxicological profile for hydrazines U.S. Department of Health and Human Services Public Health Service Agency for Toxic Substances and Disease Registry. September 1997. P. 15-16.

2. Meyer H. On hydrazine derivatives of pyridine carbonic acids / Meyer H., Mally J. // Monatshefte Chemie verwandte Teile anderer Wissenschaften. 1912. - 33: P. 393-414.

3. Бережной P. В. Руководство по судебно-медицинской експертизе отравлений / Бережной Р. В., Грибов В. М., Деньковский А. Р. - М.: Медицина, 1980. - С. 404-405.

4. Чекман И. С. Справочник по клинической фармакологии и фармакотерапии / Чекман И. С., Пелещук А. П., Пятак О. А. Киев: Здоров’я, 1986. - С. 649-650. $367-368$

5. Куценко С. А. Основы токсикологии / С. А. Куценко. Санкт-Петербург. 2012. - С.

6. Коржевський Д. Э. Основы гистологической техники / Коржевський Д. Э., Гиляров А.В. - СПб.: СпецЛит. - 2010. - С. 16-20.

7. Пирс Дж. Гистохимия теоретическая и прикладная. М.: Иностранная литер., 1962.

8. Коцюмбас Г. І. Гістологічні та гістохімічні зміни в печінці собак за отруєння ізоніазидом / Коцюмбас Г. І., Врецьона Н. П. // Науковий вісник ЛНУВМБ імені С. 3. Гжицького. 2018. - № 92, т. 20. - С. 197-202.

9. Лужников Е. А. Острые отравления / Е. А. Лужников, Л. Г Костомарова. M.: Medicina, 1989. - P. 151-153.

\section{References}

1. Toxicological profile for hydrazines U.S. Department of Health and Human Services Public Health Service Agency for Toxic Substances and Disease Registry. September 1997. P. 15-16. 
2. Meyer, H., \& Mally, J. (1912). On hydrazine derivatives of pyridine carbonic acids. Monatshefte Chemie verwandte Teile anderer Wissenschaften, 33, 393-414.

3. Berezhnoy, R. V., Gribov, V. M., \& Denkovskiy, A. R. (1980). Rukovodstvo po sudebnomeditsinskoy ekspertize otravleniy. M. Meditsina, 404-405 (in Russian).

4. Chekman, I. S., Peleschuk, A. P., \& Pyatak, O. A. (1986). Spravochnik po klinicheskoy farmakologii i farmakoterapii. Kiev «Zdorov'ya», 649-650 (in Russian).

5. Kutsenko, S. A. (2012). Osnovyi toksikologii. Sankt-Peterburg, 367-368 (in Russian).

6. Korzhevskiy, D. E., Gilyarov, A. V. (2010). Osnovyi gistologicheskoy tehniki. SPb. SpetsLit, 16-20 (in Russian).

7. Pirs, Je. (1962). Gistohimija teoreticheskaja i prikladnaja. M.: Inostr. lit. (in Russian).

8. Kotsyumbas, G. I., \& Vretsona, N. P. (2018). Gistologichni ta gistohimichni zminy v pechintsi sobak za otruennya izoniazidom. Naukovyi visnyk LNUVMB imeni S. Z. Gzhytskogo, 20 (92), 197-202 (in Ukrainian).

9. Luzhnikov, E. A., \& Kostomarova, L. G. (1989). Ostrye otravlenija. M.: Medicina, 151153 (in Russian).

Рецензент - М. І. Жила, д. вет. н., ДНДКІ ветпрепаратів та кормових добавок.

УДК 619:616.3-002-091:636.8

doi: 10.36359/scivp.2019-20-2.31

\title{
МІКРОСКОПІЧНІ ЗМІНИ В СЕЛЕЗІНЦІ КОТІВ, ЩО ЗАГИНУЛИ ВІД ІНФЕКЦІЙНОГО ПЕРИТОНІТУ
}

\author{
M. C. Kриштоп, аспірантка
}

Національний університет біоресурсів і природокористування України вул. Героїв оборони, 11, м. Київ, 03041, Україна

Представлені результати вивчення мікроскопічних змін у селезіниі котів, щзо загинули від інфекиійного перитоніту. При проведенні патологоанатомічного розтину в 19 котів нами була встановлена змішана форма інфекиійного перитоніту (73,1% випадків), а в 7 котів суха форма хвороби (26,9% випадків). При проведенні гістологічних досліджень селезінки нами було встановлено, щзо мікроскопічні зміни в цььому органі в усіх котів як при сухій, так $i$ при змішаній формах інфекиійного перитоніту були подібними та не залежали від тривалості прижиттєвого перебігу хвороби. В серозній оболониі реєструвалась виразна метаплазія клітин мезотелію та інфільтрація цієї оболонки моноцитами й лімфоцитами. $B$ червоній пульпі - майже повне зникнення еритроцитів, а в білій - різна ступінь гіперплазї лімфоїдни вузликів та їх гіпертрофія.

Ключові слова: КОТИ, ІНФЕКЦІЙНИЙ ПЕРИТОНІТ, СУХА ФОРМА, ЗМІШАНА ФОРМА, СЕЛЕЗІНКА, МІКРОСКОПІЧНІ ЗМІНИ.

Проблемам здоров’я котів нині приділяють значну увагу. Особливо значну роль у цьому плані мають інфекційні хвороби, в тому числі й інфекційний перитоніт [4]. У багатьох випадках єдиним методом точної прижиттєвої діагностики інфекційного перитоніту $\epsilon$ гістологічні дослідження біоптатів лімфовузлів чи внутрішніх органів. У частині випадків без 